\title{
Developing Context-Based Reading Materials
}

\author{
Atmazaki \\ Padang State University \\ (atmazaki@fbs.unp.ac.id)
}

\begin{abstract}
This study aimed to explain the process of developing teaching materials based on Contextual Teaching and Learning (CTL). As the basis of development, this study used 7 types of texts that should be learned in class VII SMP items, namely descriptive texts, fantasy texts, procedural texts, report texts, poetical texts, fable texts, and letters texts. The development models of Plomp is used to analyze the needs (preliminary phase), make the design (prototyping phase), and conduct field test (evaluation phase). The results show that the contextual reading of developed material meets the criteria of validity, practicality, and effectiveness. It is expected that these materials can improve reading interest and skills of the students.
\end{abstract}

Keywords-- reading skill, reading materials, contextual teaching and learning model

\section{INTRODUCTION}

The ability to read is the essence of self-education and lifelong learning because reading has a role in selfdevelopment (Tella \& Akande, 2007). Reading has a positive impact on cognitive development (Moore and Cahill, 2016; Basuki, 2011); the foundation for building other academic skills (Hassen, 2016). Therefore, the ability to read should be improved in an effort to develop an educated society (Wahyuni, 2010).

Reading skills among students should be improved through various channels, either formal or non-formal education such as in reading garden (Moore \& Cahill, 2016). On formal education, learning to read needs to be implemented more seriously, both in terms of speed and understanding. Not just being able to answer factual questions in text, but also connect with the experience, even able to respond the text content (Pineda, 2014). Through reading garden, reading skills are enhanced for aspects of passion, interest, and fun.

Through the formal education path, the government has implemented a national curriculum since 2013, called K-13. To support implementation, the Curriculum and Book Center has established a number of textbooks for all subjects. In addition, the private sector also publishes supporting books as an additional government book. However, the books are still considered to be much deficient in terms of readability (Fadilah \& Mintowati, 2015); incompleteness of the material description and learning approach (Asri, 2017); improper language usage (Purnanto \& Mastudi, 2016); and inadequate illustrations (Muslich, 2011).

One solution offered to help overcome these shortcomings is the development of teaching materials. The developed teaching material is focused on reading material for seventh grade junior high school students. Teaching materials are developed as models so that teachers can make them as examples or guides to develop their own reading material relevant to student characteristics. In addition, the teaching materials developed are tailored to the CTL approach so that learning is more student-centered, cooperative learning, self-learning, relating to daily life, not just memorization, and authentic assessment (Utomo, 2016; Sugiyono, 2010; Khotimah, \& Masduki, 2015; Khaefiatinnisa, 2015; Plomp, 1997).

Based on the stated issues and models of teaching materials offered, this study aims to explain the process of developing teaching materials to help junior high school students learn to read. Teaching materials (product research) were developed based on a contextual approach intended to motivate students and teachers in the learning process.

\section{METHOD}

The development research (Gall, Borg, and Gall, 1996) undertaken is following the Plomp (1997) model with three phases: preliminary research, prototyping phase and assessment phase. In preliminary research, needs, curriculum, students, and concepts of reading learning in junior high school are identified and analyzed. Based on the analysis of the needs, reading material is developed for the seven texts that are set. The teaching materials were developed based on CTL. The teaching materials are validated to students/teachers, and experts (prototyping phase). Once declared valid, then tested in class to know the level of its practicality and effectiveness (asessment phase).

Several instruments (questionnaires, interviews guide, and tests) were prepared to analyze field conditions, to determine suitable learning materials, and learning outcomes. The subjects of the trial were the students of grade VII SMP Padang, West Sumatra, Indonesia with three schools of SMPN 12 Padang, SMPN 8 Padang, and SMPN 30 Padang, with 220 students. Data were descriptively analyzed with product feasibility level above $75 \%$. 


\section{FINDING AND DISCUSSION}

\section{a. Preliminary Research} table 1 .

Through interviews, many things are known about the circumstances of learning to read in junior Padang as in

Table 1. Requirements Analysis

\begin{tabular}{|c|c|c|c|c|}
\hline No. & Statement & School-1 & School-2 & School-3 \\
\hline 1. & $\begin{array}{l}\text { Students' skills in reading } \\
\text { comprehension. }\end{array}$ & Good & Enough & Enough \\
\hline 2. & Time to learn to read. & Not enough & Not enough & Not enough \\
\hline 3. & Constraints in learning to read. & Limited reading sources & less time & $\begin{array}{l}\text { Low student interest in } \\
\text { reading }\end{array}$ \\
\hline 4. & $\begin{array}{l}\text { Learners read the difficult aspects } \\
\text { for students. }\end{array}$ & $\begin{array}{l}\text { Identifying information in } \\
\text { the text }\end{array}$ & $\begin{array}{l}\text { Identifying information in } \\
\text { the text }\end{array}$ & $\begin{array}{l}\text { Understanding the text } \\
\text { content }\end{array}$ \\
\hline 5. & $\begin{array}{l}\text { Connecting the material with real } \\
\text { life. }\end{array}$ & Yes & Yes & Yes \\
\hline 6. & $\begin{array}{l}\text { Students were asked to dig up } \\
\text { information on learning. }\end{array}$ & Yes & No & No \\
\hline 7. & $\begin{array}{l}\text { Guidance for students discover } \\
\text { the concept of reading } \\
\text { independently. }\end{array}$ & No & No & No \\
\hline 8. & $\begin{array}{l}\text { Referrals for students to ask in } \\
\text { learning. }\end{array}$ & Yes & Yes & No \\
\hline 9. & Cooperative learning. & Yes & Yes & Yes \\
\hline 10. & $\begin{array}{l}\text { Example text is provided for } \\
\text { comprehension. }\end{array}$ & $\begin{array}{l}\text { Yes, taken from the Internet } \\
\text { and revised }\end{array}$ & $\begin{array}{l}\text { Yes, taken from the } \\
\text { Internet and revised }\end{array}$ & No, only book sources \\
\hline 11. & $\begin{array}{l}\text { Reflection after implementing } \\
\text { learning. }\end{array}$ & No & No & No \\
\hline 12. & $\begin{array}{l}\text { Learning resources used in } \\
\text { learning. }\end{array}$ & $\begin{array}{l}\text { Textbooks of government } \\
\text { (Ministry of Education and } \\
\text { Culture) and sources on the } \\
\text { Internet }\end{array}$ & $\begin{array}{l}\text { Textbooks from Ministry } \\
\text { of Education and Culture } \\
\text { and sources on the } \\
\text { Internet }\end{array}$ & $\begin{array}{l}\text { Textbooks from Ministry } \\
\text { of Education and Culture } \\
\text { and sources on the } \\
\text { Internet }\end{array}$ \\
\hline 13. & $\begin{array}{l}\text { Text books provided by the } \\
\text { government are adequate }\end{array}$ & $\begin{array}{l}\text { Already, but still need } \\
\text { additional learning } \\
\text { resources }\end{array}$ & $\begin{array}{l}\text { Already, but still need } \\
\text { additional resources }\end{array}$ & $\begin{array}{l}\text { Already, but still need } \\
\text { additional resources }\end{array}$ \\
\hline 14. & $\begin{array}{l}\text { Advantages and disadvantages of } \\
\text { learning resources that have been } \\
\text { used. }\end{array}$ & $\begin{array}{l}\text { Examples much text is } \\
\text { displayed, but not close to } \\
\text { the student environment. }\end{array}$ & $\begin{array}{l}\text { Having a diverse tests, } \\
\text { but the matter is less } \\
\text { detailed. }\end{array}$ & $\begin{array}{l}\text { Having a diverse tests, } \\
\text { but the sample text is not } \\
\text { close to the student } \\
\text { context }\end{array}$ \\
\hline
\end{tabular}

Based on the needs analysis above, it is concluded that the learning process cannot be implemented properly because of the limitations of teaching materials both in terms of variation and in terms of contents. Especially for junior high scholl students, there are a number of texts to be learned. In reading learning, students should be able to understand, identify, and analyze texts. Thus, required reading material is what helps students improve their ability to understand, identify, and analyze texts. The expected competencies can be seen in table 2 .

Table 2. Analysis of Instructional Materials Concept and Relevance To Curriculum

\begin{tabular}{rlll}
\hline No. & \multicolumn{1}{c}{ Text Learned } & \multicolumn{1}{c}{ Comprehension } & \multicolumn{1}{c}{ Skills } \\
\hline 1. & Description text & Identifying, analyzing & Explaining, presenting data \\
2. & Story fantasy text & Identifying, analyzing & Retelling, present ideas \\
3. & Procedure text & Identifying, analyzing & Summing up, the present data \\
4. & Reports text & Identifying, analyzing & Summing up, summarizes \\
5. & Folk poetry & Identifying, analyzing & Summing up, examine \\
6. & Fables text & Identifying, analyzing & Retelling, acting \\
7. & Letter & Identifying, analyzing & Summing up, write \\
\hline
\end{tabular}

\section{b. Prototyping Phase}

Based on the needs analysis and curriculum analysis, then teaching materials relevant to the needs of learning to read is designed so learning activity can be more interesting, exciting, and motivating for the students. In general, the pattern of teaching materials developed is as shown in Figure 1. 

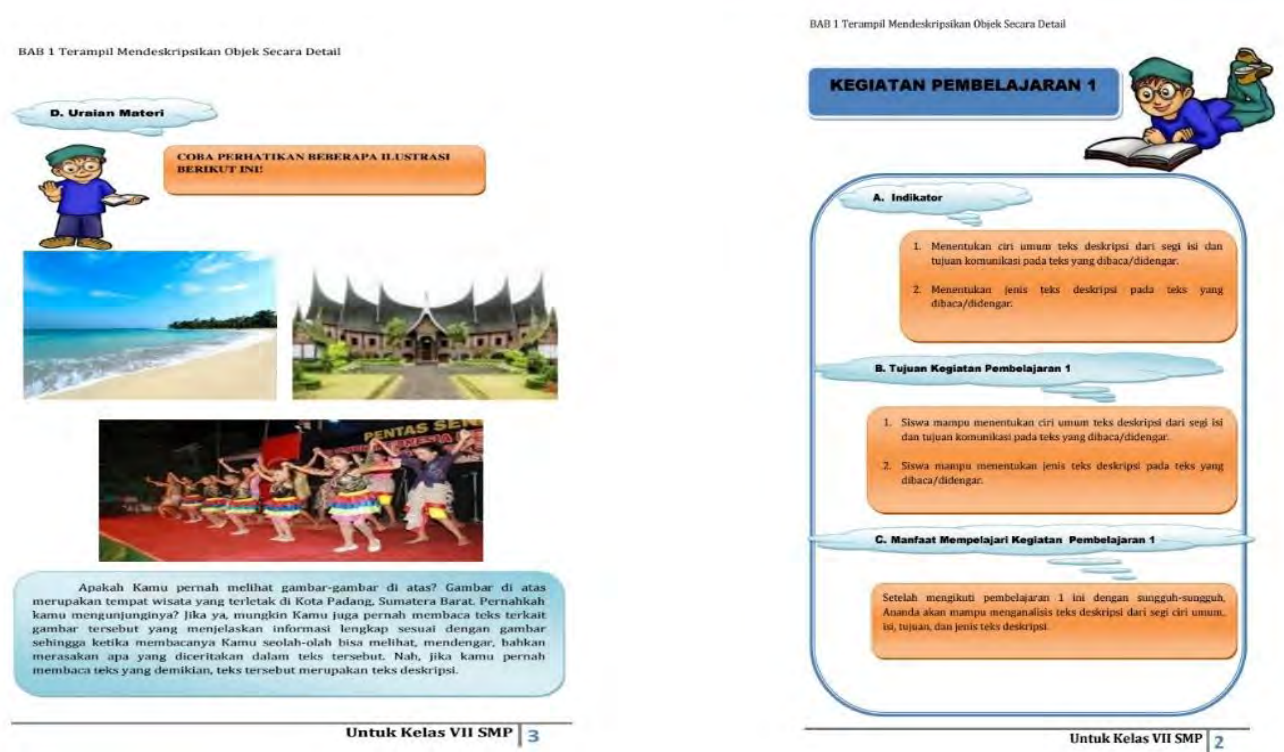

Picture 1. Design Patterns Reading Materials-Based Context

The process of making design up to validation stage is done as follows. Table 3 shows the self-evaluation of developed material reaches 88.20 (very valid). This is possible because the design has been done carefully and considered the needs analysis and student analysis.

Table 3 Self-Evaluation of Reading Materials

\begin{tabular}{|c|c|c|c|c|}
\hline No. & Rated Aspect & Indicators Rating & Validity (\%) & Category \\
\hline 1. & $\begin{array}{l}\text { Feasibility contents of } \\
\text { teaching materials }\end{array}$ & $\begin{array}{l}\text { The accuracy contents of teaching materials to } \\
\text { the curriculum } \\
\text { Concepts outlined in teaching materials } \\
\text { The contents of teaching materials }\end{array}$ & 88.89 & Very valid \\
\hline 2. & $\begin{array}{l}\text { Language in teaching } \\
\text { materials }\end{array}$ & $\begin{array}{l}\text { Sentence } \\
\text { The idea and style of presentation }\end{array}$ & 87.50 & Very valid \\
\hline \multicolumn{3}{|c|}{ Results Validation of Self-Evaluation In Overall } & 88.20 & Very valid \\
\hline
\end{tabular}

After self-evaluation, teaching materials are validated to the expert. The aspects of validation are content, language, presentation, and graphics. Validation results are presented in Table 4.

Table 4. Validation Results of Teaching Material by Expert

\begin{tabular}{|c|c|c|c|c|}
\hline No. & Rated Aspect & Indicators Rating & Validity (\%) & Category \\
\hline 1. & $\begin{array}{l}\text { Feasibility contents of } \\
\text { teaching materials }\end{array}$ & $\begin{array}{l}\text { The accuracy contents of teaching materials to } \\
\text { the curriculum } \\
\text { Material or concept } \\
\text { The contents of teaching materials }\end{array}$ & 87.50 & Very valid \\
\hline 2. & $\begin{array}{l}\text { Language in teaching } \\
\text { materials }\end{array}$ & $\begin{array}{l}\text { Sentence } \\
\text { The idea and style of presentation }\end{array}$ & 91.67 & Very valid \\
\hline 3. & Presentation materials & $\begin{array}{l}\text { Core competencies and basic competencies, } \\
\text { indicators, and the purpose of learning } \\
\text { Presentation material } \\
\text { Presentations book }\end{array}$ & 97,50 & Very valid \\
\hline 4. & $\begin{array}{l}\text { Graphics in teaching } \\
\text { materials }\end{array}$ & $\begin{array}{l}\text { Display materials } \\
\text { The use of images, colors, fonts, etc. }\end{array}$ & 88.89 & Very valid \\
\hline \multicolumn{3}{|c|}{ Validation of Teaching Material by Expert In Overall } & 92.00 & Very valid \\
\hline
\end{tabular}


Expert validation results on reading material reach a very valid level, in which content, language, learning and graphics meet the standard of good teaching materials. Similarly, the results of validation of teaching materials by teachers of Indonesian subjects as shown in Table 5. In general, teachers stated that the material is very good (very valid).

Table 5. Validation Results of Teaching Material by Teacher

\begin{tabular}{|c|c|c|c|c|}
\hline No., & Rated Aspect & Indicators Rating & Validity (\%) & Category \\
\hline 1. & $\begin{array}{l}\text { Feasibility contents of } \\
\text { teaching materials }\end{array}$ & $\begin{array}{l}\text { Material or concept } \\
\text { The contents of teaching materials }\end{array}$ & 77.78 & Valid \\
\hline 2. & $\begin{array}{l}\text { Language in teaching } \\
\text { materials }\end{array}$ & $\begin{array}{l}\text { Sentence } \\
\text { The idea and style of presentation }\end{array}$ & 77.78 & Valid \\
\hline 3. & Presentation materials & $\begin{array}{l}\text { Presentation material } \\
\text { Presentation book }\end{array}$ & 100.00 & Very valid \\
\hline 4. & $\begin{array}{l}\text { Graphics in teaching } \\
\text { materials }\end{array}$ & $\begin{array}{l}\text { Display materials } \\
\text { The use of pictures, colors, and fonts. }\end{array}$ & 88.89 & Very valid \\
\hline \multicolumn{3}{|c|}{$\begin{array}{l}\text { Total Value of Teacher Response } \\
\text { Response Teacher In Overall }\end{array}$} & $\begin{array}{c}344.45 \\
\mathbf{8 6 . 1 1}\end{array}$ & Very valid \\
\hline
\end{tabular}

Prior to use in the classroom, students were also asked to comment on the reading materials developed. The validation of the students is done through a questionnaire of 220 students. The results can be seen in Table 6 .

Table 6. Results of Student Response

\begin{tabular}{|c|c|c|c|c|c|}
\hline \multirow[t]{2}{*}{ No. } & \multirow[t]{2}{*}{ Statement } & \multicolumn{2}{|c|}{$\begin{array}{c}\text { Answer } \\
\text { Students }\end{array}$} & \multirow{2}{*}{$\begin{array}{l}\text { Validity Value } \\
(\%)\end{array}$} & \multirow[t]{2}{*}{ Category } \\
\hline & & Yes & No & & \\
\hline 1. & $\begin{array}{l}\text { Understand the material / concepts presented in teaching } \\
\text { materials. }\end{array}$ & 203 & 17 & 92.27 & Very valid \\
\hline 2. & The materials encourage curiosity. & 213 & 7 & 96.82 & Very valid \\
\hline 3. & Teaching materials encourage learning effectively. & 208 & 12 & 94.54 & Very valid \\
\hline 4. & Sentences that are simple, clear, and easy to understand. & 212 & 8 & 96.36 & Very valid \\
\hline 5. & The idea of good order. & 215 & 5 & 97.73 & Very valid \\
\hline 6. & The delivery style of teaching materials communicative. & 203 & 17 & 92.27 & Very valid \\
\hline 7. & Presentation material or section title is short and clear. & 215 & 5 & 97.73 & Very valid \\
\hline 8. & $\begin{array}{l}\text { Presentation materials and establish motivating to ask the } \\
\text { public to learn. }\end{array}$ & 205 & 15 & 93.18 & Very valid \\
\hline 9. & Teaching materials come with instructions for use. & 217 & 3 & 98.64 & Very valid \\
\hline 10. & $\begin{array}{l}\text { The order of presentation of teaching materials prepared } \\
\text { properly. }\end{array}$ & 217 & 3 & 98.64 & Very valid \\
\hline 11. & Views increase interest and motivation to learn. & 217 & 3 & 98.64 & Very valid \\
\hline 12 & $\begin{array}{l}\text { Illustration is interesting and appropriate to the learning } \\
\text { material. }\end{array}$ & 208 & 12 & 94.54 & Very valid \\
\hline 13. & Variations in the use of color increase the motivation to learn. & 216 & 4 & 98.18 & Very valid \\
\hline 14. & $\begin{array}{l}\text { Conformity type and size of letters with the level of } \\
\text { development of students. }\end{array}$ & 216 & 4 & 98.18 & Very valid \\
\hline \multicolumn{4}{|c|}{ Total Value of Students Response } & 1347.73 & \multirow{2}{*}{ Very valid } \\
\hline \multicolumn{3}{|c|}{ Values of Student Response In Overall } & & 96.27 & \\
\hline
\end{tabular}

Overall prototyping stage is successful. This is evident from the responses of students, teachers, and experts. Almost all respondents stated that the teaching materials developed fit for use because it fits the context of the students, the language easily understood, and learning procedures easier for students to understand, answer questions, and to apply it in real life. In addition, illustrations and font size suit the students.

\section{c. Assessment Phase}

After the teaching materials declared valid by the respondents, then trials were conducted in three schools (SMPN 8 Padang, Padang SMPN 12, and SMPN 31 Padang). In the testing phase, the level of practicality and effectiveness of reading materials are assessed. Practical values are collected through questionnaires and interviews, and effectiveness values are collected through knowledge tests. The results of practicality can be seen in table 7 (teachers), 8 (students), 9 (learning activities), the effectiveness can be seen in Table 10 (student attitudes) and 11 (student learning outcomes). 
Table 7 Results The practicalities by Teachers

\begin{tabular}{|c|c|c|c|c|}
\hline No. & Rated Aspect & Indicators Rating & Practicalities $(\%)$ & Category \\
\hline 1. & Presentation & $\begin{array}{l}\text { Accuracy of KI, KD, indicators and learning } \\
\text { objectives } \\
\text { Presentation material }\end{array}$ & 98.61 & Very practical \\
\hline 2. & Ease of use & $\begin{array}{l}\text { Ease of use materials } \\
\text { The contents of reading materials } \\
\text { Benefits application of reading materials }\end{array}$ & 98.11 & Very practical \\
\hline 3. & Legibility & Readability of reading materials & 100.00 & Very practical \\
\hline 4. & Time used & Practicality application of read ing materials & 88.89 & Very practical \\
\hline $\begin{array}{l}\text { Tot } \\
\text { Pra }\end{array}$ & $\begin{array}{l}\text { Value Practicalitie } \\
\text { calities Value by T }\end{array}$ & $\begin{array}{l}\text { eachers } \\
\text { In Overall }\end{array}$ & $\begin{array}{c}385.61 \\
96.40\end{array}$ & Very practical \\
\hline
\end{tabular}

Next, practicalities of students. The practicalities value obtained through interviews are conducted with 220 students. Results of the practicalities of such students can be seen in the following table.

Table 8. Practicalities Results of Reading Materials by Students

\begin{tabular}{|c|c|c|c|c|c|}
\hline \multirow[t]{2}{*}{ No. } & \multirow{2}{*}{ Statement } & \multicolumn{2}{|c|}{$\begin{array}{l}\text { Answer } \\
\text { Students }\end{array}$} & \multirow{2}{*}{$\begin{array}{l}\text { Practicalities } \\
\text { Value }(\%)\end{array}$} & \multirow{2}{*}{ Category } \\
\hline & & Yes & No & & \\
\hline 1. & Interest in teaching materials. & 214 & 6 & 97.0 & Very practical \\
\hline 2. & Teaching materials can enhance the spirit of learning. & 211 & 9 & 96.0 & Very practical \\
\hline 3. & The benefits of teaching materials in everyday life. & 211 & 9 & 95.9 & Very practical \\
\hline 4. & The linkage concept or learning materials to read. & 215 & 5 & 97.7 & Very practical \\
\hline 5. & $\begin{array}{l}\text { Teaching materials are easy to read, understand, and } \\
\text { remember. }\end{array}$ & 204 & 16 & 92.7 & Very practical \\
\hline 6. & $\begin{array}{l}\text { Time spent is not unnecessarily long because it is easy to } \\
\text { understand. }\end{array}$ & 204 & 16 & 92.7 & Very practical \\
\hline 7. & $\begin{array}{l}\text { Helping self-learning without any explanation from the } \\
\text { teacher. }\end{array}$ & 203 & 17 & 92.3 & Very practical \\
\hline \multicolumn{2}{|c|}{ Total Value Practicalities by Students } & & & 664.0 & \multirow{2}{*}{ Very practical } \\
\hline \multicolumn{2}{|c|}{ Practicalities Value by Students In Overall } & & & 95.0 & \\
\hline
\end{tabular}

Tables 7, 8, and 9 show that, the teaching materials are easy to use, attractive; it can also increase student interest. In general, teachers and students stated that these materials practical. More specifically, through interviews, the students stated that the teaching materials developed are exciting, enhance the spirit of learning, related to everyday life, easy to understand and help independent learning.

Table 9. Results of Student Learning Activities

\begin{tabular}{|c|c|c|c|c|}
\hline No. & Statement & $\begin{array}{c}\text { frequency } \\
\text { of Activities }\end{array}$ & $\begin{array}{l}\text { Percentage } \\
\text { Activity }\end{array}$ & Category \\
\hline 1. & $\begin{array}{l}\text { Studying the teaching materials in accordance with the instructions } \\
\text { provided. }\end{array}$ & 192 & 87.27 & Very active \\
\hline 2. & Digging for information or comprehension based learning topics. & 192 & 87.27 & Very active \\
\hline 3. & Finding itself the concept readings based learning topics. & 181 & 82.27 & Very active \\
\hline 4. & $\begin{array}{l}\text { Obtaining information through activity based learning topics } \\
\text { asked. }\end{array}$ & 187 & 85.00 & Very active \\
\hline 5. & Cooperate and a variety of learning experiences with the group. & 192 & 87.27 & Very active \\
\hline 6. & Carried out an inquiry to identify the examples provided. & 196 & 89.09 & Very active \\
\hline 7. & Presenting instructional feedback & 174 & 79.09 & Active \\
\hline 8. & Working on performance tests appropriate given problem & 220 & 100.00 & Very active \\
\hline \multicolumn{3}{|c|}{$\begin{array}{l}\text { Total Value Student Activity } \\
\text { Value Student Activity In Overall }\end{array}$} & $\begin{array}{c}697.26 \\
87.16\end{array}$ & Very active \\
\hline
\end{tabular}

Next is the effectiveness of teaching materials. This phase is done through attitude assessment and student learning outcomes. The value of student attitudes is obtained through observation of the value of attitude sheet. The value of student attitudes will be based on classroom research. The experiments were conducted in seven classes. Each class studied the text. Student attitudes can be seen in table 10. 
Table 10. Results of Student Attitudes

\begin{tabular}{|c|c|c|c|c|c|c|c|c|}
\hline \multirow[b]{2}{*}{ No. } & \multirow[b]{2}{*}{ School } & \multirow[b]{2}{*}{ Text that Tested } & \multirow{2}{*}{$\begin{array}{c}\text { Number of } \\
\text { Students } \\
\text { Trial } \\
\end{array}$} & \multicolumn{3}{|c|}{ Percentage Rate Attitude } & \multirow[b]{2}{*}{ Value } & \multirow[b]{2}{*}{ Predicate } \\
\hline & & & & $\mathbf{A}$ & B & $\mathbf{C}$ & & \\
\hline \multirow{3}{*}{1.} & \multirow{3}{*}{ SMP N 8 Padang } & Story Fantasy Text & 32 & 91.67 & 88.54 & 89.58 & 89.93 & $\mathrm{~A}$ \\
\hline & & Procedure Text & 32 & 91.67 & 90.63 & 90.63 & 90.97 & $\mathrm{~A}$ \\
\hline & & Fables Text & 30 & 91.11 & 90.00 & 90.11 & 90.37 & A \\
\hline \multirow{2}{*}{2.} & \multirow{2}{*}{ SMP N 12 Padang } & Description Text & 31 & 94.62 & 95.69 & 95.69 & 95.34 & A \\
\hline & & Letter & 31 & 89.25 & 88.17 & 89.25 & 88.89 & $\mathrm{~A}$ \\
\hline \multirow{2}{*}{3.} & \multirow{2}{*}{ SMP N 31 Padang } & Reports Text & 32 & 97.92 & 84.38 & 92.71 & 91.67 & A \\
\hline & & Folk Poetry & 32 & 94.79 & 90.63 & 92.71 & 92.71 & A \\
\hline \multicolumn{3}{|c|}{$\begin{array}{l}\text { Total Value Attitude Students } \\
\text { Value Attitude Students In Overall }\end{array}$} & & $\begin{array}{c}651.03 \\
93,00\end{array}$ & $\begin{array}{c}628.04 \\
89.72\end{array}$ & $\begin{array}{c}640.68 \\
91.53\end{array}$ & $\begin{array}{c}693.88 \\
91.41\end{array}$ & A \\
\hline
\end{tabular}

Next, student learning outcomes. Student learning outcomes obtained through the ability to read text. The test is tested in the form of a multiple-choice objective test. The value of students' reading ability test can be seen in Table 11 below.

Table 11. Results Of Student Learning Outcomes Scores

\begin{tabular}{|c|c|c|c|c|c|}
\hline No. & School & The Text To Be Tested & $\begin{array}{c}\text { Number of } \\
\text { Students Trial }\end{array}$ & Value & Predicate \\
\hline \multirow{3}{*}{1.} & \multirow{3}{*}{ SMP N 8 Padang } & Story Fantasy Text & 32 & 83.88 & $\mathrm{~B}$ \\
\hline & & Procedure Text & 32 & 84.31 & $\mathrm{~B}$ \\
\hline & & Fables Text & 30 & 75.00 & $\mathrm{~B}$ \\
\hline \multirow{2}{*}{2.} & \multirow{2}{*}{ SMP N 12 Padang } & Description Text & 31 & 78.28 & $\mathrm{~B}$ \\
\hline & & Letter & 31 & 80.65 & $\mathrm{~B}$ \\
\hline \multirow{2}{*}{3.} & \multirow{2}{*}{ SMP N 31 Padang } & Reports Text & 32 & 80.23 & $\mathrm{~B}$ \\
\hline & & Folk Poetry & 32 & 80.06 & $\mathrm{~B}$ \\
\hline \multicolumn{3}{|c|}{$\begin{array}{l}\text { Students Reading Ability Test Scores } \\
\text { Reading Ability Values In Overall }\end{array}$} & & $\begin{array}{r}562.41 \\
\mathbf{8 0 . 3 4}\end{array}$ & B \\
\hline
\end{tabular}

\section{Discussion}

Analysis of preliminary research (students, curriculum, and concepts) showed that it is important to develop reading materials on learning Indonesian literature, especially for reading skills. Indonesian learning in Curriculum 2013 (Core Competence and Basic Competence) focus on language and text as the basis (Regulation of the Minister of Education and Culture No. 24/2016).

In the preliminary research, it was found that the instructional materials used by students in the school have not been able to support the learning process. This caused the material factors become unexhaustive and detailed, learning materials do not attract students to read, and the presentation of material in the teaching materials are not connected to real life contexts of students, so that learning becomes less meaningful. Based on this, it is necessary to develop a model of instructional materials that can serve as an example for teachers to develop teaching materials that suit the needs of students.

Next, based on the prototyping phase, is the development of reading materials. Model reading materials developed by considering four issues, namely the aspect of content, presentation, linguistic, and graphics. First, on the content, reading materials developed consists of seven text is descriptive texts, fantasy story texts, procedure texts, report texts, folk poetry, fable texts, and letters. Second, reading materials are developed based on CTL. The structure of reading material consists of an introduction, materials, and evaluation. Third, the language used according to the students who use the materials to be easily understood. Fourth, reading materials furnished with illustrations and some other suitable supporting elements in order to be interesting reading materials.

Reading materials have been designed, it was further validated, in order to obtain a valid material (content, presentation, linguistic, and graphics). This is in line with Emzir (2010, p. 273), who argues that the validation is the process of product design assessment done by giving a rating based on rational thinking. Validated reading materials must meet the eligibility criteria in terms of the validity of the content, language, presentation, and graphics (Depdiknas, 2008 , p. 28). Based self-evaluation of teaching materials developed reached very valid category with $88.20 \%$ validity. Thereafter, reading materials were validated to experts. In this study, the validation is performed by four experts according to their expertise. Based on the validity by experts, teaching materials developed very valid category with $92 \%$ of validity. Furthermore, validation reading materials by the response of teachers and students each amounting to $86.11 \%$ and $96.27 \%$. This is in accordance with the opinion of Riduwan (2014: 15) who states that value interval of 81100 is a very valid category. Based on these values, teaching materials can be tested at schools.

Valid teaching materials are tested to the school for practical value (presentation, ease of use, legibility, and time spent) and effectiveness (student learning activities, attitudes and learning outcomes) of teaching materials. This 
activity is part of the assessment phase. Experiments in question is trying out materials that have been validated to some samples of learning objectives (Daryanto, 2013, p. 51-52). The results showed that the teaching materials developed are very practical with the practicalities by teacher and students respectively $96.4 \%$ and $95 \%$. This is in accordance with the opinion of Riduwan (2014, p. 15) who states that the interval of 81-100 is very practical. Thus, developed teaching materials are easy to understand, easy to use, and have enough time to use. Teachers revealed that the materials used are very helpful in learning reading, because the texts are diverse, close to the students, includes a variety of evaluation tools and guidelines for the assessment of reading skills.

Lastly, this study performed testing on the effectiveness of reading materials. The effectiveness of reading materials used is determined by student learning outcomes (Kemp, 1994, p. 320). The results showed reading materials developed very effective category with 80.34 for the value of student learning outcomes, and 91.41 for the value of student attitudes.

\section{CONCLUSION AND RECOMMENDATION}

Based on the discussion, it can be concluded that in general Indonesian language teachers only use materials provided by the ministry of education and culture. The teaching materials have not been able to support the learning process. Therefore, it is necessary to develop models of teaching materials that can serve as a model for teachers to develop their own teaching materials and tailored to the needs of students and can be linked to real-life contexts of students as well.

Through some phase of activities that have been carried out, this study produced a reading materials based on CTL for seventh-grade junior high school students, which consists of seven texts. Development activity in this study starts with preliminary research, then design reading materials and validated to see the validity. After teaching materials were valid, teaching materials were tested at school. The results of research trials show that teaching materials are practical and effective for learning to read for seventh-grade students Indonesian junior high schools. Based on these results, it is expected that teachers can develop their own teaching materials to be used as additional teaching materials for the main teaching to suit the needs of students and can be linked to the real-life context of students, especially for reading skills.

\section{References}

Asri, S. (2017). Telaah buku teks pegangan guru dan siswa pada mata pelajaran bahasa indonesia kelas VII berbasis kurikulum 2013. RETORIKA: Jurnal Ilmu Bahasa, 3 (1), 70-82.

Basuki, I. A. (2016). Kemampuan membaca pemahaman siswa kelas IV SD berdasarkan tes internasional dan tes lokal. Jurnal Bahasa dan Seni, 39 (2), 202-212.

Daryanto. (2013). Penyusunan modul (bahan ajar untuk persiapan guru dalam mengajar). Yogyakarta: Gava Media.

Depdiknas. (2008). Panduan pengembangan bahan ajar. Jakarta. Direktorat Jendral Pendidikan Dasar dan Menengah Direktorat Pembinaan sekolah Menengah Atas.Diana, P. Z. (2014). Teknik membaca SQ3R dalam membaca kritis untuk penguatan pendidikan karakter di perguruan tinggi. CARAKA, 1 (1), 31-40.

Emzir. (2010). Metodologi penelitian pendidikan:kuantitatif dan kualitatif. Jakarta: Rajawali Pers.

Fadilah, R. \& Mintowati, M. (2015). Buku teks bahasa indonesia SMP dan SMA kurikulum 2013 terbitan kementerian pendidikan dan kebudayaan 2014. Jurnal Pena Indonesia (JPI), 1 (1).

Hassen, R. (2016). Reading habits of secondary school teacher: A study of selected secondary school in Addis Ababa and Dessie. Journal of Educational Practice, 7 (22), 59-67.

Kemp, J. E. (1994). Designing effective instruction. New York:Macmilla.

Khaefiatinnisa (2010). The effectiviness of contextual teaching in improving student's reading skill in procedural text. Journal of English and Education, 3 (1), 80-95.

Khotimah, R. P. \& Masduki (2016). Improving teaching quality and problem solving ability through contextual teaching and learning in differential equations: A lesson study approach. Journal of Research and Advences in Mathematics Education, 1 (1), 1-13.

Muslich, M. (2011). KTSP: pembelajaran berbasis kompetensi dan kontekstual, panduan bagi guru, kepala sekolah, dan pengawas sekolah. Bumi Aksara.

Moore, J. \& Cahill, M. (2016). Audiobooks: legitimate 'reading' material for adolescents? Research Journal of the American Association of School Librarians, 19, 1-17.

Plomp, Tj. (1997). Educational design: introduction. from tjeerd plomp (eds). educational \& training system design: introduction. design of educatio and training (in Dutch). Utreecht (the Netherlands): Lemma. Netherland. Faculty of Educational Science and Technology, University of Twente.

Purnanto, A. W., \& Mustadi, A. (2016). Analisis kelayakan bahasa dalam buku teks tema 1 kelas I sekolah dasar kurikulum 2013. Profesi Pendidikan Dasar, 3(2), 111-119.

Pineda, D. (2014). The Feasibility of Assessing Teenagers' Oral English Language Performance with a Rubric. Profile, $16(1), 1657-790$. 
Riduwan. (2012). Skala pengukuran variabel-variabel penelitian. Bandung: Alfabeta.

Tella, A. \& Akande, S. (2007). Children's reading habits and availability of books in Bostwana primary schools: Implications for achieving quality education. The Reading Matrix, 7 (2).

Utomo, B. (2016). Effect contextual teaching learning compact disk-based interactive media learning and motivation against mathematics learning outcomes. Proceeding of International Research Clinic \& Scientific Publication of Educational Technology. 504-515.

Wahyuni, S. (2010). Menumbuhkan minat baca menuju masyarakat literat. Jurnal Diksi, 17 (1), 179 —189. 